\title{
Grafting-Take Success in Walnut (Juglans regia) under Different Environment Conditions
}

\section{R.A. Wani*, Jahangeer A. Baba, Gul Zaffar, S.A. Hakeem, I. Umar, M.A. Mir, B.A. Alie, Seerat-un-Nissa, Sabiya Bashir, Niyaz A. Dar and Mohd Zubair}

\author{
Dry land (Krewa) Agriculture Research Station Budgam, SKUAST-Kashmir, \\ Jammu and Kashmir, India-191113 \\ *Corresponding author
}

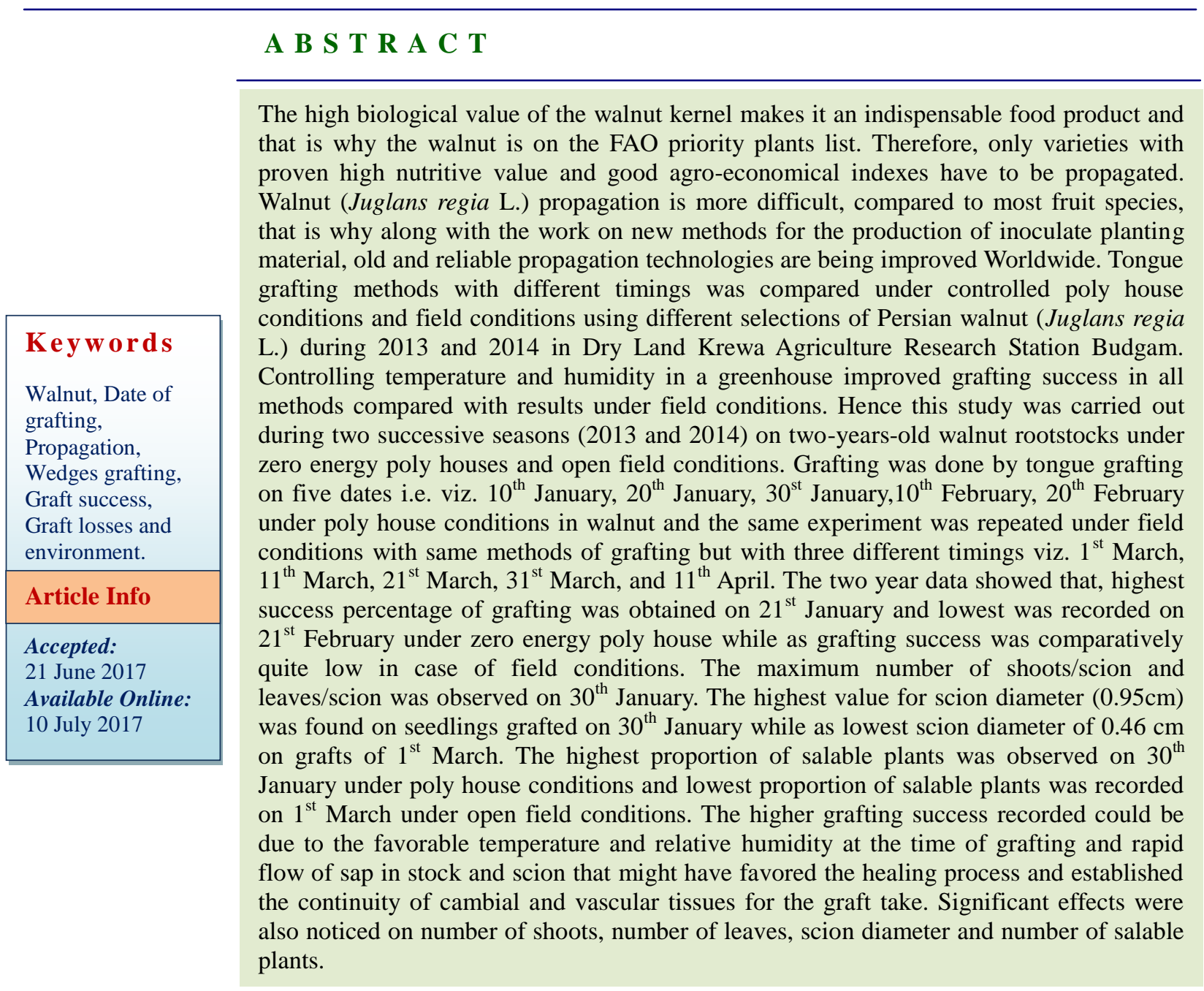

\section{Introduction}

Walnut belongs to the family Juglandaceae and has wide adaptability to grow in temperate regions of the world between "1,200 to $2,150 \mathrm{~m}$ " above sea level. Persian 
walnut (Juglans regia L.) is one of the main nut crops in Central Asia, and is especially important in India. It is extensively grown almost in all the temperate countries of world where the summers are not too cool or too hot. In India it is grown in Jammu and Kashmir, Uttar Pradesh and Himachal Pradesh. Jammu Kashmir is principal walnut growing state having monopoly in the production of export quality nuts. In Jammu and Kashmir, is presently grown on an area of 89788 ha with annual production of 163745 million tonnes (Anonymous, 2012). The existing plantations in the world are generally of seedling orgin and notably variable in production and nut quality (Ozkan et al., 2001). For a long time in the past, propagation through seed was only method available for walnut multiplication though this practice resulted into plants of great variability (Rongting et al., 1993). Selections of promising walnut cultivars in these populations along with the market demand for better quality products have increased interest in vegetative propagation of this species (Vahdati, 2003). Grafting in walnuts is more difficult than in other fruit trees (Vahdati, 2005; Vahdati, 2006) and poor grafts take has always been considered a drawback in mass propagation of superior walnut selections (Ozkan et al., 2001). Temperature and humidity have major effects on the process of walnut graft uniting (Karadeniz, 2005; Sutyemez, 2007). Specially changing in temperature among the uniting period has direct effect on callus development and successful grafting (Rongting et al., 1993). Environmental conditions during and after grafting, have a major impact on callus formation environmental conditions during and after grafting, have a major impact on callus formation in walnut (Avanzato et al., 1997). Best temperature for walnut grafting is $27^{\circ} \mathrm{C}$ (Avanzato et al., 1997; Ozkan et al., 2001; Vahdati, 2006). In this temperature, callus formation occurs five days after grafting but in $22^{\circ} \mathrm{C}$ callus formation begins in seven days after grafting, and in temperatures lower than $20^{\circ} \mathrm{C}$ no callus formation occurs (Rezaee et al., 2008). Low temperature in winters is the most important limiting factor for walnut grafting at this season and to avoid it, $27^{\circ} \mathrm{C}$ condition have to be provided for 3-4 weeks (Rongting et al., 1993; Vahdatim, 2006). Also high environmental moisture is needed for winter grafting, because the parenchyma cells of callus have soft walls and they lose their moisture in dry places and poor grafts take has always been considered a drawback in mass propagation of superior walnut selections (Vahdati, 2003; Rongting et al., 1993). Accordingly, outdoor grafting is always restricted by the time of year when such favorable temperatures can be expected (Hartmann et al., 2001; Karadeniz, 2005).Various methods of vegetative propagation in walnut have been reported to give varying degree of success under different climatic conditions in India and abroad. The variations are dependent on different environmental conditions to which the plants are subjected before and after propagation (Ibrahim et al., 1978; Awasthi et al., 1982; Qureshi et al., 1985). Different techniques of grafting have been examined by several researchers to improve the temperature and humidity effects by using controlled environmental conditions (Achim et al., 2001; Avanzato, 2001), however most of these methods were inefficient, expensive, and not applicable on a large scale. The tongue grafting method is one of the best methods of propagation for fruit trees in nurseries. The best time to tongue grafting is dormant season before growth starts (El. Sayed et al., 2000). It has been found to be quite successful in the month of February, when both the stocks and scions were in dormant conditions. The best technique to increase the production of grafted plant material is to adopt vegetative propagation under poly houses. Keeping in 
view the importance of increasing the demand of grafted plants, the present study was conducted to compare the efficiency of walnut grafting time under greenhouse conditions for producing walnut plants in different months of a year and in different areas than those currently in use. In fact, there is an urgent need to standardize the suitable techniques for clonal multiplication of walnut in order to ensure supply of quality plant material for expansion of area, achieve increase in production and productivity of superior nuts and meeting the international standards of quality characters of nut and kernel.

\section{Materials and Methods}

An experiment to study the graft-take success in walnut (Juglans regia L.) under different environmental conditions was carried out at the experimental field of "Dryland (Krewa) Agriculture research Station" Budgam, SKUAST- Kashmir during two consecutive years 2013 and 2014. The experimental site is located at an elevation of " $1587 \mathrm{~m}$ " above mean sea level and situated at $34.08^{\circ}$ North latitude and $74.08^{\circ}$ East longitude. The experiment was carried out under poly house and in open field conditions with same method of grafting viz. tongue but with different timing, viz. $10^{\text {th }}$ January, $20^{\text {th }}$ January, 30 ${ }^{\text {th }}$ January, 10 ${ }^{\text {th }}$ February, 20 $0^{\text {th }}$ February under poly house and $1^{\text {st }}$ March, $10^{\text {th }}$ March and 20 ${ }^{\text {th }}$ March, 30 ${ }^{\text {th }}$ March, $10^{\text {th }}$ April in open field conditions (Tables 2 and 4). The seedlings of walnuts having pencil size thickness or more were transplanted in all the playhouses. The scion material was collected from elite sources already identified trees. The bud sticks used for grafting were one year old terminal shoots. The scion was 10-15 $\mathrm{cm}$ long with 3-4 buds. The basal end was cut in a long gently sloping wedge of $5 \mathrm{~cm}$ long, then inserted in the split of stock, wrapped with polyethylene strips and covered with grafting wax. Temperature and humidity were maintained in all the playhouses during two consecutive years. Since temperature and humidity have crucial effects on the healing process, they were recorded during the experiment using a maximum minimum thermometer and a hygrometer, respectively (Table 1). Percentage of union success for the grafting was recorded one month after each date. Number of shoots and number of leaves per scion were counted in August. Mean shoot length and scion diameter $(5 \mathrm{~cm}$ above grafting union) were measured in August. The observations were recorded on number of shoots/ scion, number of leaves/scion, scion diameter $(\mathrm{cm})$, grafting success $(\%)$ and proportion of saleable plants (\%). The experiment was laid in a Completely Randomized Design (CRD) using three replications. Statistical analyses were conducted using the SAS and means were compared by critical difference (CD) at 0.05 .

\section{Results and Discussion}

The data on the graft-take success in walnut under polyhouse and open field conditions are given in tables 2, 3 and 4. Results revealed that union success percentage in walnut was significantly affected by grafting dates. Maximum grafting success $80.43 \%$ was recorded $30^{\text {th }}$ January, followed by $72.33 \%$ on $20^{\text {th }}$ January under poly house conditions while as grafting in open field conditions showed little success which was statistically non-significant. The success percentage obtained on $30^{\text {th }}$ January under poly house was statistically significant with all grafting dates. Grafting in green house found more successful than grafting on dormant seedlings by (Kantrachi, 1989). However minimum success percentage (41.04) was observed on $20^{\text {th }}$ February under poly house. The maximum grafting success in tongue grafting under poly house during the month of January might be due to the fact that the favorable 
temperature and relative humidity at the time of grafting and rapid sap flow in stock and scion favored the healing process and established the continuity of cambial and vascular tissues for the graft take. The comparatively lower percentage of success in February grafting in comparison to the January grafting might due to the fact that in February tissue attains active growth and loses their tolerance to injury. These results are partially in harmony with the finding on pecan trees and (Abou-Rayya et al., 2009) on almond cv. Ne plus ultra. Analysis of data in table 2, 3 and 4 revealed that January grafting gave significantly higher number of shoots than from the seedlings which were grafted in February. The highest number of shoots/ scion (5.70) was observed from seedlings which were grafted on $30^{\text {th }}$ January under poly house and were statistically significant from rest of treatment dates while as lowest number of shoots/scion (3.07) was observed from seedlings which were grafted on $20^{\text {th }}$ March. (Zaen et al., 2011) Reported that pistachio trees grafted by cleft or side grafting methods in January gave higher significant number of shoots than from the trees which were grafted by the same method in February date in both studied seasons (2013 and 2014 long period of growth of the grafts. These results are partially in harmony with the finding on pecan trees, (Muzaffar et al., 2011) on walnut and (Zaen et al., 2011) on pistachio trees. Our) which support our findings.

Table.1 Average temperature $\left({ }^{\circ} \mathrm{C}\right)$ and relative humidity $(\%)$ in greenhouse and outside

\begin{tabular}{|c|c|c|c|c|c|c|c|c|}
\hline \multirow{2}{*}{ Month } & \multicolumn{2}{|c|}{$\begin{array}{c}\text { Greenhouse } \\
\text { temperature }\end{array}$} & \multicolumn{2}{c|}{$\begin{array}{c}\text { Outside } \\
\text { temperature }\end{array}$} & \multicolumn{2}{c|}{$\begin{array}{c}\text { Greenhouse } \\
\text { humidity }\end{array}$} & \multicolumn{2}{c|}{$\begin{array}{c}\text { Outside } \\
\text { humidity }\end{array}$} \\
\cline { 2 - 9 } & $\mathbf{2 0 1 3}$ & $\mathbf{2 0 1 4}$ & $\mathbf{2 0 1 3}$ & $\mathbf{2 0 1 4}$ & $\mathbf{2 0 1 3}$ & $\mathbf{2 0 1 4}$ & $\mathbf{2 0 1 3}$ & $\mathbf{2 0 1 4}$ \\
\hline January & 15.89 & 17.65 & 1.99 & 3.56 & 43.67 & 45.25 & 70.54 & 79.34 \\
\hline February & 17.61 & 19.21 & 3.49 & 4.98 & 56.89 & 59.45 & 74.56 & 78.56 \\
\hline March & 18.45 & 21.98 & 9.87 & 12.64 & 65.87 & 62.76 & 64.24 & 66.75 \\
\hline April & 20,67 & 24,21 & 11.25 & 14.53 & 65.25 & 68.94 & 62.65 & 57.90 \\
\hline
\end{tabular}

Table.2 Effect of grafting time on graft success, number of shoots and Number of leaves in polyhouse

\begin{tabular}{|c|c|c|c|c|c|c|c|c|c|c|c|c|c|}
\hline \multirow[t]{2}{*}{$\begin{array}{l}\text { Time of } \\
\text { grafting }\end{array}$} & \multicolumn{2}{|c|}{$\begin{array}{l}\text { No. of plants } \\
\text { grafted }\end{array}$} & \multicolumn{2}{|c|}{$\begin{array}{l}\text { No. of } \\
\text { successful } \\
\text { grafts }\end{array}$} & \multicolumn{2}{|c|}{ Success (\%) } & \multirow[t]{2}{*}{$\begin{array}{l}\text { Pooled } \\
\text { Succes } \\
\text { ses }(\%)\end{array}$} & \multicolumn{2}{|c|}{$\begin{array}{l}\text { No. of } \\
\text { shoots/scion }\end{array}$} & \multirow[t]{2}{*}{$\begin{array}{l}\text { Pooled } \\
\text { No. of } \\
\text { shoots/ } \\
\text { scion } \\
\end{array}$} & \multicolumn{2}{|c|}{$\begin{array}{l}\text { No. of } \\
\text { leaves/scion }\end{array}$} & \multirow[t]{2}{*}{$\begin{array}{l}\text { Pooled } \\
\text { No. of } \\
\text { leaves/ } \\
\text { scion } \\
\end{array}$} \\
\hline & 2013 & 2014 & 2013 & 2014 & 2013 & 2014 & & 2013 & 2014 & & 2013 & 2014 & \\
\hline $10^{\text {th }}$ January & 152 & 167 & 105 & 119 & 69.07 & 71.25 & 70.16 & 3.8 & 4.1 & 3.95 & 32.89 & 29.65 & 31.27 \\
\hline $20^{\text {th }}$ January & 176 & 182 & 126 & 133 & 71.59 & 73.07 & 72.33 & 3.14 & 3.65 & 3.39 & 34 & 37 & 35.5 \\
\hline $30^{\text {th }}$ January & 211 & 197 & 167 & 161 & 79.14 & 81.72 & 80.43 & 5.09 & 6.32 & 5.70 & 43.19 & 44.25 & 43.72 \\
\hline $10^{\text {th }}$ February & 189 & 185 & 110 & 101 & 58.20 & 54.59 & 56.39 & 4.39 & 4.98 & 4.68 & 31 & 33.75 & 32.37 \\
\hline $20^{\text {th }}$ February & 156 & 168 & 64 & 69 & 41.02 & 41.07 & 41.04 & 2.95 & 3.19 & 3.07 & 28.49 & 24.89 & 26.69 \\
\hline SEM \pm & & & & & 0.89 & 0.94 & 0.92 & 0.09 & 0.03 & 0.07 & 0.39 & 0.38 & 0.43 \\
\hline $\mathrm{CD}(\mathrm{P}=0.05)$ & & & & & 2.6 & 2.73 & 2.81 & 0.15 & 0.11 & 0.19 & 1.41 & 1.40 & 1.48 \\
\hline
\end{tabular}


Table.3 Effect of grafting time on scion diameter and number of salable plants in poly house

\begin{tabular}{|c|c|c|c|c|c|c|c|c|c|c|}
\hline \multirow{2}{*}{$\begin{array}{l}\text { Time of } \\
\text { grafting }\end{array}$} & \multicolumn{2}{|c|}{$\begin{array}{l}\text { No. of plants } \\
\text { grafted }\end{array}$} & \multicolumn{2}{|c|}{$\begin{array}{l}\text { No. of successful } \\
\text { grafts }\end{array}$} & \multicolumn{2}{|c|}{$\begin{array}{l}\text { Scion diameter } \\
(\mathrm{cm})\end{array}$} & \multirow{2}{*}{$\begin{array}{l}\text { Pooled } \\
\text { scion } \\
\text { diameter } \\
(\mathrm{cm})\end{array}$} & \multicolumn{2}{|c|}{$\begin{array}{l}\text { No. of salable } \\
\text { plants }(\%)\end{array}$} & \multirow{2}{*}{$\begin{array}{l}\text { Pooled } \\
\text { No. of } \\
\text { salable } \\
\text { plants } \\
(\%)\end{array}$} \\
\hline & 2013 & 2014 & 2013 & 2014 & 2013 & 2014 & & 2013 & 2014 & \\
\hline $10^{\text {th }}$ January & 152 & 167 & 105 & 119 & 0.87 & 0.85 & 0.86 & 52.35 & 54.77 & 53.56 \\
\hline $20^{\text {th }}$ January & 176 & 182 & 123 & 135 & 0.83 & 0.93 & 0.88 & 58.00 & 60.82 & 59.16 \\
\hline $30^{\text {th }}$ January & 211 & 197 & 167 & 145 & 0.97 & 0.93 & 0.95 & 65.39 & 68.54 & 66.96 \\
\hline $10^{\text {th }}$ February & 189 & 185 & 110 & 101 & 0.91 & 0.93 & 0.92 & 55.29 & 58.25 & 56.77 \\
\hline $20^{\text {th }}$ February & 156 & 168 & 64 & 69 & 0.81 & 0.79 & 0.80 & 44.77 & 46.61 & 45.69 \\
\hline SEM \pm & & & & & & & 0.003 & 0.72 & 0.75 & 0.69 \\
\hline $\mathrm{CD}(\mathrm{P}=\mathbf{0 . 0 5})$ & & & & & & & 0.01 & 2.21 & 2.35 & 2.16 \\
\hline
\end{tabular}

Table.4 Effect of time of grafting on graft success, scion diameter, number of leaves/scion and Number of salable plants under open field conditions

\begin{tabular}{|c|c|c|c|c|c|c|c|c|c|c|c|c|c|c|c|c|}
\hline \multirow[t]{2}{*}{$\begin{array}{l}\text { Time of } \\
\text { grafting }\end{array}$} & \multicolumn{2}{|c|}{$\begin{array}{l}\text { No. of plants } \\
\text { grafted }\end{array}$} & \multicolumn{2}{|c|}{$\begin{array}{l}\text { No. of } \\
\text { successful } \\
\text { grafts }\end{array}$} & \multicolumn{2}{|c|}{ Success (\%) } & \multirow{2}{*}{$\begin{array}{l}\text { Pooled } \\
\text { Succes } \\
\text { ses (\%) }\end{array}$} & \multicolumn{2}{|c|}{$\begin{array}{l}\text { Scion } \\
\text { diameter }(\mathrm{cm})\end{array}$} & \multirow{2}{*}{$\begin{array}{l}\text { Pooled } \\
\text { scion } \\
\text { diameter } \\
\text { (cm) }\end{array}$} & \multicolumn{2}{|c|}{$\begin{array}{l}\text { No. of } \\
\text { leaves/scion }\end{array}$} & \multirow{2}{*}{$\begin{array}{l}\text { Pooled } \\
\text { No. of } \\
\text { leaves/ } \\
\text { scion }\end{array}$} & \multicolumn{2}{|c|}{$\begin{array}{l}\text { No of salable } \\
\text { plants }(\%)\end{array}$} & \multirow{2}{*}{$\begin{array}{l}\text { No of } \\
\text { salable } \\
\text { plants } \\
(\%)\end{array}$} \\
\hline & 2013 & 2014 & 2013 & 2014 & 2013 & 2014 & & 2013 & 2014 & & 2013 & 2014 & & 2013 & 2014 & \\
\hline $1^{\text {st }}$ March & 152 & 167 & 18 & 20 & 11.8 & 11.9 & 11.85 & 0.43 & 0.49 & 0.46 & 17.8 & 19.6 & 18.7 & 21.1 & 22.5 & 21.8 \\
\hline $10^{\text {th }}$ March & 176 & 182 & 22 & 26 & 12.5 & 14.2 & 13.35 & 0.59 & 0.51 & 0.55 & 24.7 & 21.9 & 23.3 & 24.6 & 27.2 & 25.9 \\
\hline $21^{\text {st }}$ March & 211 & 197 & 34 & 31 & 16.1 & 15.7 & 15.9 & 0.65 & 0.71 & 0.68 & 31.1 & 34 & 32.55 & 32 & 28.0 & 30.0 \\
\hline $30^{\text {th }}$ March & 189 & 185 & 23 & 21 & 12.1 & 11.3 & 15.7 & 0.62 & 0.57 & 0.59 & 34.0 & 37.0 & 35.5 & 35.0 & 37.4 & 36.2 \\
\hline $10^{\text {th }}$ April & 156 & 168 & 20 & 23 & 12.8 & 13.6 & 13.2 & 0.77 & 0.74 & 0.75 & 41.3 & 43.7 & 42.5 & 42.5 & 45.6 & 44.05 \\
\hline SEM \pm & & & & & NS & NS & NS & 0.002 & 0.002 & 0.002 & 0.21 & 0.23 & 0.29 & 0.47 & 0.51 & 0.32 \\
\hline $\mathrm{CD}(\mathbf{P}=\mathbf{0 . 0 5})$ & & & & & NS & NS & NS & 0.01 & 0.01 & 0.01 & 0.92 & 0.94 & 1.09 & 1.89 & 1.95 & 1.69 \\
\hline
\end{tabular}

Fig.1 Effect of grafting time on Graft success, No. of shoots/ scion, No. of leaves/ scion,

Scion diameter $(\mathrm{cm})$ and number of salable plants in poly house

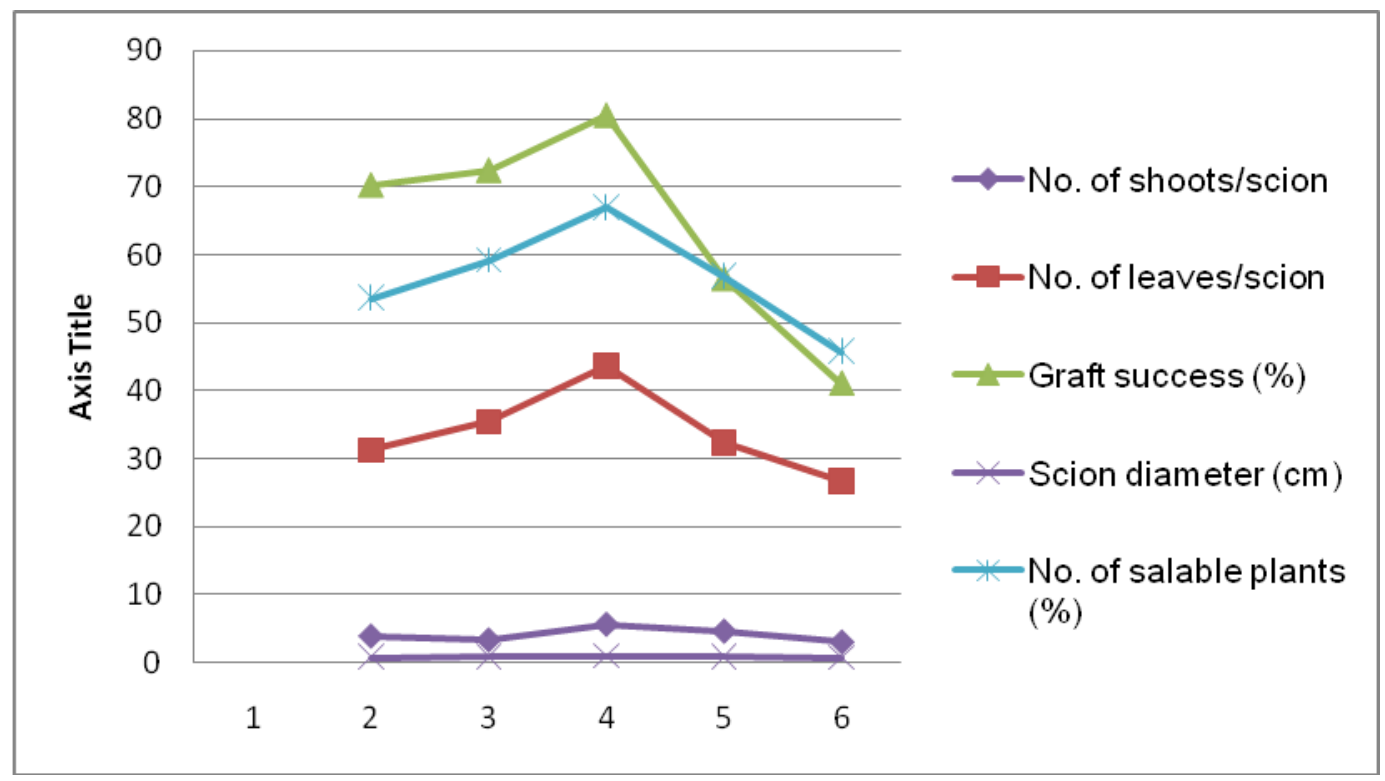


Regarding, number of leaves highest values (43.72) was recorded from seedlings which were grafted on $30^{\text {th }}$ January followed by 35.50 on $20^{\text {th }}$ January while the lowest number 26.69 was recorded on seedlings grafted on $20^{\text {th }}$ March while as under open field conditions highest leaves/scion were recorded on $10^{\text {th }}$ April and lowest 18.7 on $10^{\text {th }}$ February. Grafting in green house was found more successful than grafting on dormant seedlings by (Kantrachi, 1989). He concluded that different dates of grafting gave better results in walnut. (Dar, 2003) Who observed that the environmental conditions greatly affected the grafting success and growth parameters in walnut? Similar findings have also been reported by several researchers (Chandel et al., 1998) (Fig. 1).

Data in Table 3 indicated that scion diameter was significantly influenced by grafting dates. The maximum scion diameter of $0.94 \mathrm{~cm}$ was observed from seedlings grafted on 25 January which is statistically superior from rest of grafting dates while as minimum of $0.45 \mathrm{~cm}$ was recorded from seedlings grafted on 25 March. Data on number of salable plants (\%) presented in Table 3 revealed that the salable percentage of plants were significantly influenced by time of grafting. The highest proportion of saleable plants (59.43) was obtained when grafting was performed on 15 January and was statistically at par with the seedling grafted on 5 January while as lowest proportion of saleable plants (36.65) was obtained when grafting was performed on 25 March. The highest number of shoots, leaves, scion diameter and proportion of salable plants might be due to quick union formation, early bud sprouting and availability of results also suggest that January grafting produces better bud-take, number of leaves and scion growth as compared with February and March grafting (Qian-Chun et al., 2000) also observed the higher percentage of success in walnut, when grafting was done during dormant season. Obviously, the new findings in the recent decades allowed the improvement of traditional walnut propagation methods. Based on this study it is recommended that the best time for grafting of walnut is $20^{\text {th }}$ January to $10^{\text {th }}$ February under poly house conditions and grafting of walnut under open field conditions is not remunerative on commercial scale. This method results in high graft survival throughout the separate years.

\section{References}

Abou-Rayya, M.S., Kasim, N.E., Shaheen, M.A., Yehia, T.A. and Ali, E.L. 2009. Morphological and anatomical evaluation of different budding and grafting methods and times of Ne plus ultra almond cultivar. J. Appl. Sci. Res., 5(3): 253-262.

Achim, Ch. and Botu, I. 2001. Results in walnut propagation by using different methods. Acta Horticulturae, 442: 503510.

Anonymous. 2012. Area and production statement. Department of Horticulture J \& K Government.

Avanzato, D. 2001. Effect of different hygrothermic environments on growth of potted walnut grafted seedlings. Acta Hortculturae, 544: 459-464.

Avanzato, D. and Atefi, J. 1997. Walnut grafting by heating the graft point directly in the field. Acta Hortculturae, 442: 291-4.

Awasthi, D.N., Sinha, M.M., Srivastava, R.P. and Misra, R.S. 1982. Evaluation of epictoyl grafting in walnut in relation to success and survival. Progressive Horticulture, 14: 178-179.

Chandel, J.S., Negi, K.S. and Jindal, K.K. 1998. Studies on vegetative propagation in kiwi (Actinidia deliciosa Cher). Indian J. Horticulture, 55(1): 52-54. 
Dar. 2003. Studies on walnut grafting as affected by rootstocks thickness, nut hardiness and environmental conditions. MSc thesis submitted to the Sher-eKashmir University of Agricultural Sciences and Technology, Kashmir, J\&K, India.

El. Sayed, Emtithal, H., El-Sherif, A.H., Said, W.T. and Sari El-Deen, S.A.. 2000. Studies on the technique of top working for old pecan trees. Egyptian J. Appl. Sci., 15(5): 132-46.

Hartmann, H.T., Kester, D.E., Davies, F. and Geneve, R.L. 2001. Plant Propagation: Principles and Practices, 7th edition. Prentice Hall International, Inc., NJ.

Ibrahim, M., Sadiq, C.M. and Idris, C.M. 1978. Experiment on comparative studies on different propagation techniques in English walnut (Juglans regia L). J. Agri. Res. Pak., 16(2): 205209.

Kantrachi, M. 1989. The effects of different conditions and methods on the grafting of walnuts. Doga Turk Tarim ve ormancilik Dergisi, 13(3b): 1089-1095.

Karadeniz, T. 2005. Relationships between graft success and climatic values in walnut (Juglans regia L), J. Central European Agri., 6: 631-4.

Muzaffar Mir and Ajay Kumar. 2011. Effect of different methods, time and environmental conditions on grafting in walnut. Int. J. Farm Sci., 1(2): 17-22.

Ozkan, Y. and Gumus, A. 2001. Effects of different applications on grafting under controlled conditions of walnut. Acta Hortculturae, 544: 515-520.

Ozkan, Y., Edizer, Y. and Akca, Y. 2001. A study on propagation with patch budding of some walnut (Juglans regia L.) cultivars. Acta Hortculturae, 544: 521-525.

Qian-Chun and Qian, C. 2000. Study on walnut seedling grafting techniques. South China Fruit, 29(6): 45.
Qureshi, A.S. and Dalal, M.A. 1985. Status of nut crops in Jammu and Kashmir state. Progressive Horticulture, 17: 197-205.

Rayees, A., Wani, A.Q. Reshi, Shafeeq, A. Hakeem, Sabiya Bashir, Seerat-u-nissa and Gul. Effect of time and environment on grafting success in walnut (Juglans regia) in Krewa soils of India Abstract published in $11^{\text {th }} \mathrm{JK}$ Science congress 2015 entitled, "Scientific, Social and Economic Dimensions of Climate Change", University of Kashmir Srinagar from 12-14 ${ }^{\text {th }}$ October, 2015 pp 43.

Rezaee, R., Vahdati, K., Grigoorian, V. and Lizade, M. 2008. Walnut grafting success and bleeding rate as affected by different grafting methods and seedling vigor. J. Horticultural Sci. Biotechnol., 83: 94-99.

Rongting, X. and Pinghai, D. 1993. A study on the uniting process of walnut grafting and the factors affecting. Acta Horticulturae, 311: 160- 172.

Sharma, A.K., Singh, S.R., Srivastava, K.K. and Sounduri, A.S. 2003. Studies on success of walnut grafting as affected by time and environment. Indian $J$. Ecol., 18: 123-125.

Sutyemez, M. 2007. Determination of pollen production and quality of some local and foreign walnut genotypes in Turkey. Turkish J. Agri., 31:109-114.

Vahdati, K. 2003. Nursery Management and Grafting of Walnut. Khaniran Publication, Tehran.

Vahdati, K. 2006. Evaluation of Side stup and hypocotyle grafting efficiency for walnut propagation in Iran. Acta Horticulturae, 705: 347-351.

Zaen El-Deen, E.M.A. and Abd El-Rhman, I.E. 2011. Studies on grafting methods and dates of pistachio trees under supplemental irrigation in North Sinai. Res. J. Agri. Sci., 7(6): 456-63. 


\section{How to cite this article:}

Wani, R.A., Jahangeer A. Baba, Gul Zaffar, S.A. Hakeem, I. Umar, M.A. Mir, B.A. Alie, Seerat-un-Nissa, Sabiya Bashir, Niyaz A. Dar and Mohd Zubair. 2017. Grafting-Take Success in Walnut (Juglans regia) under Different Environment Conditions. Int.J.Curr.Microbiol.App.Sci. 6(7): 2195-2201. doi: https://doi.org/10.20546/ijcmas.2017.607.257 